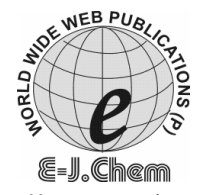

http://www.e-journals.net
ISSN: 0973-4945; CODEN ECJHAO

E-Journal of Chemistry 2010, 7(2), 369-376

\title{
One-Pot Synthesis, X-Ray Diffraction and MAS NMR Spectroscopic Study of Gallosilicate Nitrate Cancrinite $\mathrm{Na}_{8}\left[\mathrm{GaSiO}_{4}\right]_{6}\left(\mathrm{NO}_{3}\right)_{4}\left(\mathrm{H}_{2} \mathrm{O}\right)_{6}$
}

\author{
ASHOK V. BORHADE* ${ }^{*}$ and SANJAY G. WAKCHAURE \\ *Department of Chemistry, \\ HPT Arts and RYK Science College, Nasik 422005, India. \\ Department of Chemistry, \\ S.V.M. Engineering College, Nasik 422101, India. \\ ashokborhade2007@yahoo.co.in
}

Received 25 August 2009; Accepted 20 October 2009

\begin{abstract}
One-pot synthetic gallosilicate nitrate cancrinite (CAN) framework topology have been synthesized under hydrothermal conditions at $100{ }^{\circ} \mathrm{C}$. The synthesized product was characterized by, X-ray powder diffraction, IR, Raman and ${ }^{29} \mathrm{Si},{ }^{23} \mathrm{Na}$ MAS NMR spectroscopy, SEM and thermogravimetry. The crystal structure refinement of pure nitrate cancrinite has been carried out from X-ray data using Rietveld refinement method. Gallosilicate cancrinite $\mathrm{Na}_{8}\left[\mathrm{GaSiO}_{4}\right]_{6}\left(\mathrm{NO}_{3}\right)_{4}\left(\mathrm{H}_{2} \mathrm{O}\right)_{6}$ crystalline hexagonal with space group $\mathrm{P}_{3}$ and $\mathrm{a}=12.77981 \AA(2), \mathrm{c}=5.20217 \AA(1),\left(\mathrm{R}_{\mathrm{wp}}=0.0696 \mathrm{R}_{\mathrm{p}}=0.0527\right)$. The results by MAS NMR spectroscopy confirmed the alternating $\mathrm{Si}$, Ga ordering of the gallosilicate framework for a $\mathrm{Si} / \mathrm{Ga}$ ratio of 1.0. A distribution of the quadrupolar interaction of the sodium cations caused by the enclatherated water molecules and motional effects can be suggested from the ${ }^{23} \mathrm{Na}$ MAS NMR. Thermogravimetric investigation shows the extent of nitrate entrapment, stability within the cancrinite cage and decomposition properties. SEM clearly shows the hexagonal needle shaped crystals of nitrate cancrinite.
\end{abstract}

Keywords: Cancrinite, Gallo silicate, Rietveld refinements, MAS NMR, Nitrate.

\section{Introduction}

Cancrinite is one of the rocks forming group of mineral. The cancrinite and cancrinite like minerals show interesting structural features such as commensurate and incommensurate superstructures, stacking fault and a wide range of anion diadochies. From the early work ${ }^{1-4}$, the structure of cancrinite is now well known. Cancrinite has close relations to the zeolites, due to its porous structure ${ }^{5}$. The wide main channel is filled with cations and intra crystalline 
nitrate anions beside water. The $\varepsilon$-cages contain only cation and water molecules; they can be exchanged with cations by diffusion in an exchange experiments or by hydrothermal synthesis. Though, cancrinite found limited technical application, there are some publications which report the industrial applications of the cancrinite ${ }^{6-8}$. Cancrinite with enclathration of anions like sulphide, thiosulphate, selenium $\mathrm{OH}^{-}, \mathrm{Cl}^{-}, \mathrm{HCO}_{3}{ }^{-}$and $\mathrm{SO}_{4}^{-2}$ are also been reported ${ }^{6,7,9,10}$. But, synthetic cancrinite may involve some difficulties in the formation of pure phase cancrinite as well as incomplete conversion of the educts and large amounts of amorphous material obtained. Secondly, the gallosilicate cancrinite containing nitrate as a guest anion is not yet discussed in detail.

The aim of present study is, (1) to reveal the suitable range for the crystallization of pure phase nitrate cancrinite with the ideal composition $\mathrm{Na}_{8}\left[\mathrm{GaSiO}_{4}\right]_{6}\left(\mathrm{NO}_{3}\right)_{4}\left(\mathrm{H}_{2} \mathrm{O}\right)_{6}$, (2) to investigate its thermal stability and (3) to characterize the gallosilicate nitrate cancrinite, without cocrystallization of sodalite or intermediate disordered phases between cancrinite and sodalite.

\section{Experimental}

Cancrinites may be synthesized by low temperature hydrothermal reactions and high temperature solid state sintering. In the present study, one-pot synthesis of $\mathrm{Na}_{8}\left[\mathrm{GaSiO}_{4}\right]_{6}\left(\mathrm{NO}_{3}\right)_{4}\left(\mathrm{H}_{2} \mathrm{O}\right)_{6}$ cancrinite was performed hydro thermally from a gel with $1: 1$ stoichiometry for gallium and silica. The synthesis was carried out in a single step without precursors in $50 \mathrm{~mL}$ capacity teflon autoclaves at a temperature of $100{ }^{\circ} \mathrm{C}$ and autogenous pressure for reaction time of seven days. The stiochiometric amount of gallium oxide (source of gallium), silicic anhydride (source of silicon) along with $\mathrm{NaOH}$ (as a mineralizing agent) and sodium salt of nitrate were taken in a teflon autoclave. After the reaction period, the product was washed with deionized water and dried overnight at $100{ }^{\circ} \mathrm{C}$ to remove weakly adsorbed surface water.

\section{Characterization}

The characterization of $\mathrm{Na}_{8}\left[\mathrm{GaSiO}_{4}\right]_{6}\left(\mathrm{NO}_{3}\right)_{4}\left(\mathrm{H}_{2} \mathrm{O}\right)_{6}$ cancrinite was performed by X-ray powder diffraction method using Rietveld refinement program GSAS ${ }^{11}$. The X-ray powder diffraction data were collected, using diffractometer operating in $\theta-\theta$ geometry $\left(5<2 \theta<90^{\circ}\right.$, step width $0.017^{\circ} 2 \theta$, sample time 1 s per step), using $\mathrm{CuK} \alpha$ radiation.

The refinement for 40 variables and 4233 observations resulted in final agreement factors of $\mathrm{Rp}=0.0527\left(\mathrm{Rp}=\sum\left|\mathrm{y}_{\mathrm{o}}-\mathrm{cy}_{\mathrm{o}}\right| \sum \mathrm{y}_{\mathrm{o}}\right)$ and $\mathrm{Rwp}=0.0696\left(\mathrm{Rwp}=\left[\sum \mathrm{w}\left(\mathrm{y}_{\mathrm{o}}-\mathrm{cy}_{\mathrm{c}}\right)^{2} / \sum\right.\right.$ $\left.\left.\mathrm{wy}_{\mathrm{o}}{ }^{2}\right]^{1 / 2}\right), \mathrm{c}$ is a scale factor.

Those species which are encapsulated into the cancrinite cages during crystal growth i.e. nitrate and water molecules were distinguished by means of IR spectroscopy using 8400S Shimadzu FTIR spectrophotometer (as KBr pellets) and Raman Spectroscopy using Nicolet Almega XR dispersive Raman Spectrophotometer (Thermo Electron Corporation) with $780 \mathrm{~nm}$ Laser.

Apart from X-ray diffraction results, additional structural information could be estimated using MAS NMR spectroscopy of ${ }^{29} \mathrm{Si}$ and ${ }^{23} \mathrm{Na}$ MAS NMR nucleus, performed on a Bruker solid state MAS NMR, DSX 300 spectrophotometer. The ${ }^{29} \mathrm{Si}$ MAS NMR spectrum was recorded at $59.62 \mathrm{MHz}$ with $5 \mathrm{usec}$ pulse duration, $15 \mathrm{sec}$ pulse delay and a spinning rate of $5 \mathrm{KHz}$. Up to 831 scans were accumulated at a rotation frequency in a $5 \mathrm{~mm}$ probe (Tetramethylsilane as a internal standard). The ${ }^{23} \mathrm{Na}$ MAS NMR spectrum was recorded at $79.39 \mathrm{MHz}$ with $40.5 \mathrm{usec}$ pulse duration, $1 \mathrm{sec}$ pulse delay and a spinning rate of $5 \mathrm{KHz}$. Up to 112 scans were accumulated at a rotation frequency in a $5 \mathrm{~mm}$ probe 
(sodium chloride is used as a internal standard). The crystal morphology and EDAX of nitrate cancrinite was carried out using Scanning Electron microscopy on a JEOL JEM6360A model equipped with JEOL JEC-560 auto carbon coater SEM.

The degree of filling of the cancrinite framework with guest species, thermal stability of encapsulated $\mathrm{NaNO}_{3}$ and framework was checked by thermogravimetry using Metlor Toledo instrument at a heating rate $10{ }^{\circ} \mathrm{C} / \mathrm{min}$.

\section{Results and Discussion}

Using one-pot hydrothermal reactions, the synthesized product was obtained as white polymicrocrystal in nature. Under the appropriate reaction conditions, experiment shows the complete conversion of the starting materials in to nitrate cancrinite. A product of the composition $\mathrm{Na}_{8}\left[\mathrm{GaSiO}_{4}\right]_{6}\left(\mathrm{NO}_{3}\right)_{4}\left(\mathrm{H}_{2} \mathrm{O}\right)_{6}$ has been selected for all the structural investigations.

\section{IR and Raman spectroscopy}

The IR spectrum (Figure 1) shows both symmetric and asymmetric T-O-T, (where T = Ga or Si) modes of vibration for the cancrinite framework ${ }^{12,13}$. The spectra also provide evidence for the enclathration of the nitrate group in the cancrinites. Apart from a weak band at $830 \mathrm{~cm}^{-1}$, spectrum shows $v_{\text {as }}$ vibrations for the nitrate group near 1383 to $1450 \mathrm{~cm}^{-1}$ range. Weak bands at $1627 \mathrm{~cm}^{-1}$ and in the region $3000-3600 \mathrm{~cm}^{-1}$ can be assigned to the bending mode of water molecules that are absorbed in cancrinite channels.

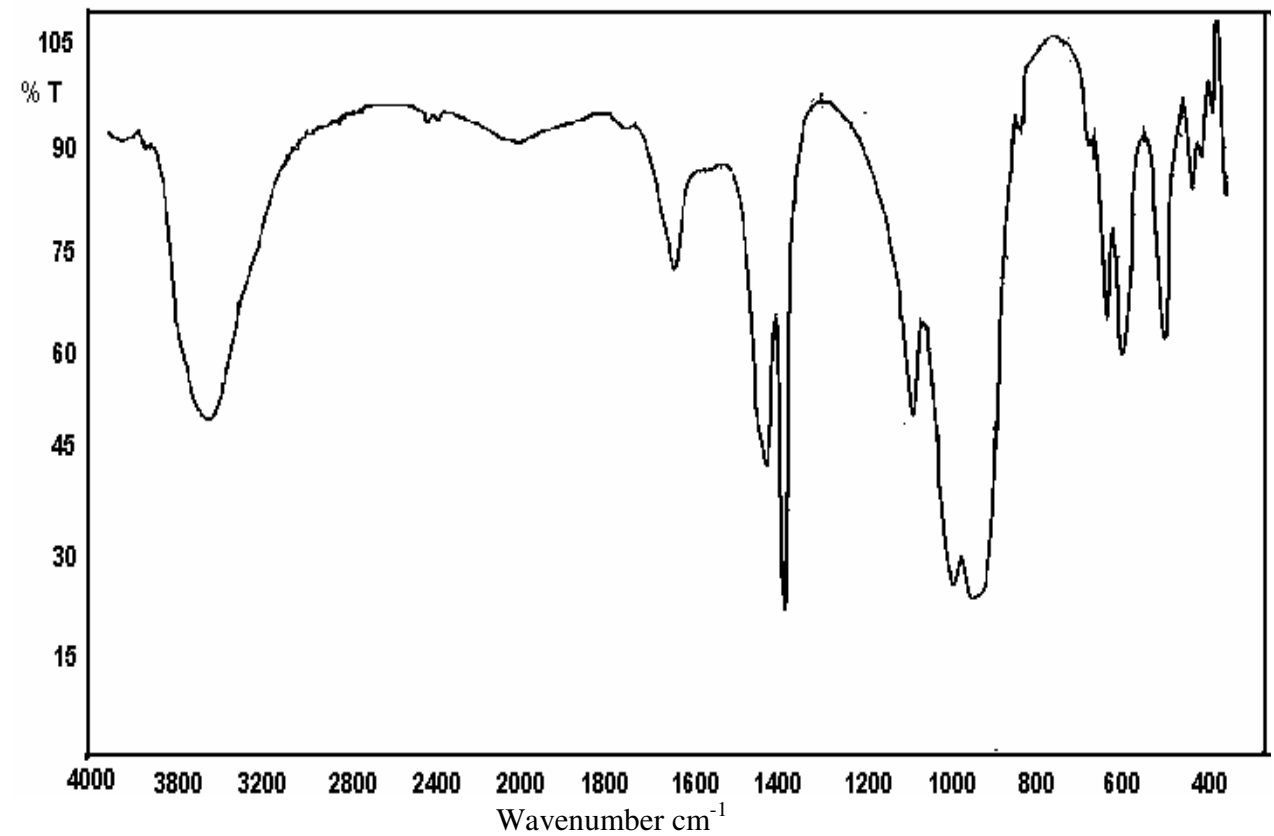

Figure 1. IR spectrum of gallosilicate nitrate cancrinite.

The Raman spectrum of gallosilicate nitrate cancrinite is shown in Figure 2. The Raman bands of nitrate gallosilicate cancrinite at $181 \mathrm{~cm}^{-1}, 319 \mathrm{~cm}^{-1}$ and $488 \mathrm{~cm}^{-1}$ (T-O deformation mode), $592 \mathrm{~cm}^{-1}$ (symmetric T-O-T vibration), $1057 \mathrm{~cm}^{-1}$ can also be classified as framework bands. 


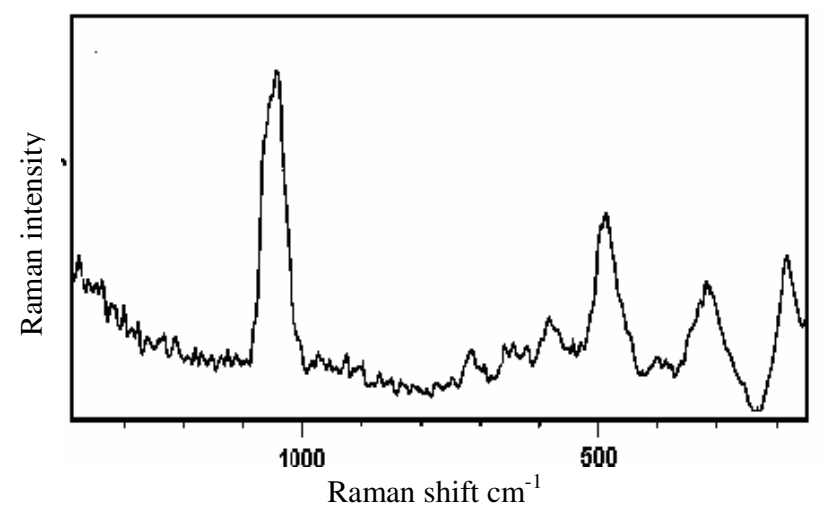

Figure 2. Raman spectrum of gallosilicate nitrate cancrinite

\section{Structure refinement}

The structural arrangement of the encapsulated nitrate is new and more interesting because of the arrangement of the sodium cations in the cancrinite channel and $\varepsilon$-cages. The literature survey shows that many reports are available on structural arrangement of salt molecules in the aluminosilicate cancrinite and little attention is given on encapsulation of salt molecule in gallosilicate cancrinite. The crystallographic data and experimental conditions for the structure refinement of nitrate gallosilicate cancrinite are given in Table 1.

Table 1. Crystallographic data and experimental conditions for the structure refinement of gallosilicate nitrate cancrinite

\begin{tabular}{ll}
\hline $\mathrm{Na}_{8}\left[\mathrm{GaSiO}_{4}\right]_{6}\left(\mathrm{NO}_{3}\right)_{4}\left(\mathrm{H}_{2} \mathrm{O}\right)_{6}$ & \\
\hline Temperature & $20{ }^{\circ} \mathrm{C}$ \\
Crystal system and Space group & $\mathrm{Hexagonal,} \mathrm{P}_{3}$ \\
Cell parameter $(\AA)$ & $\begin{array}{l}\mathrm{a}=12.77981 \AA(2) \\
\mathrm{c}=5.20217 \AA(1)\end{array}$ \\
& 1488.31 \\
Molecular weight, $\mathrm{g} \mathrm{mol}^{-1}$ & 3.359 \\
Density $(\mathrm{d}) \mathrm{g} \mathrm{cm}^{-3}$ & 735.808 \\
Cell Volume V $(\AA)$ & \\
Data collection & $5-90$ \\
$2 \theta$ range $\left(^{\circ}\right)$ & 0.017 \\
Step size $(2 \theta)$ & 1 \\
Sample time (s/data point) & 40 \\
Number of refined parameters & $\mathrm{Rp}=0.0527$ \\
Agreement factors & $\mathrm{Rwp}=0.0696$ \\
\hline
\end{tabular}

The refinement was done, on considering nitrate aluminosilicate cancrinite as a starting model. During the refinement all non specific positional parameters were allowed to vary together with the displacement parameters of all atoms. The resulting residuals for this refinement are $\mathrm{Rp}=0.0527, \mathrm{Rwp}=0.0696$. A plot of observed X-ray powder pattern with difference between observed and calculated intensities is shown in Figure 3. The powder XRD pattern shows only reflections resulting from cancrinite and is consistent with space group $\mathrm{P}_{3}$. The intensity distribution and reflections show that there are no indications of the presence of extraneous phases or amorphous materials. Atomic positions, displacement parameters are listed in Table 2 and selected geometrical data is given in Table 3. 
Table 2. Fractional coordinates and equivalent displacement parameters of nitrate cancrinite.

\begin{tabular}{ccccc}
\hline Atom & site & $\mathrm{x}$ & $\mathrm{y}$ & $\mathrm{z}$ \\
\hline $\mathrm{Ga}$ & $\mathbf{6 c}$ & $0.0824670(0)$ & $0.6664200(0)$ & $0.2330590(0)$ \\
$\mathrm{Si}$ & $\mathbf{6 c}$ & $0.0740000(0)$ & $0.4134000(0)$ & $0.2209000(0)$ \\
$\mathrm{O} 1$ & $\mathbf{6 c}$ & $0.3546220(0)$ & $0.5962130(0)$ & $0.3548600(0)$ \\
$\mathrm{O} 2$ & $\mathbf{6 c}$ & $0.9529620(0)$ & $0.6363240(0)$ & $0.4491930(0)$ \\
$\mathrm{O} 3$ & $\mathbf{6 c}$ & $0.8333960(0)$ & $0.2344210(0)$ & $0.4188740(0)$ \\
$\mathrm{O} 4$ & $\mathbf{6 c}$ & $0.1488220(0)$ & $0.5769760(0)$ & $0.3095050(0)$ \\
$\mathrm{Na} 1$ & $\mathbf{2 b}$ & $0.3333000(0)$ & $0.6667000(0)$ & $0.1831780(0)$ \\
$\mathrm{O} 5$ & $\mathbf{6 c}$ & $0.2911210(0)$ & $0.6173690(0)$ & $0.7393560(0)$ \\
$\mathrm{Na} 2$ & $\mathbf{6 c}$ & $0.1293570(0)$ & $0.2580040(0)$ & $0.7336450(0)$ \\
$\mathrm{N} 1$ & $\mathbf{2 a}$ & $0.0000000(0)$ & $0.0000000(0)$ & $0.4300550(0)$ \\
$\mathrm{O} 6$ & $\mathbf{6 c}$ & $0.9856540(0)$ & $0.8980550(0)$ & $0.5868360(0)$ \\
$\mathrm{N} 2$ & $\mathbf{2 a}$ & $0.0000000(0)$ & $0.0000000(0)$ & $0.7904270(0)$ \\
$\mathrm{O} 7$ & $\mathbf{6 c}$ & $0.9697350(0)$ & $0.8435020(0)$ & $0.9246450(0)$ \\
\hline
\end{tabular}

Table 3. Selected derived bond distances and bond angles for nitrate $\mathrm{Na}_{8}\left[\mathrm{GaSiO}_{4}\right]_{6}\left(\mathrm{NO}_{3}\right)_{4}\left(\mathrm{H}_{2} \mathrm{O}\right)_{6}$ cancrinite.

\begin{tabular}{cccc}
\hline Bond distances & $(\AA)$ & Bond distances & $(\AA)$ \\
\hline $\mathrm{Ga}(1)-\mathrm{O}(4)$ & $1.77573(11)$ & $\mathrm{Si}(1)-\mathrm{O}(2)$ & $1.51706(16)$ \\
$\mathrm{Ga}(1)-\mathrm{O}(2)$ & $1.87477(11)$ & $\mathrm{Si}(1)-\mathrm{O}(4)$ & $1.87028(12)$ \\
Average & 1.82525 & Average & 1.69367 \\
$\mathrm{Na}(1)-\mathrm{O}(1)$ & $1.38882(9)$ & $\mathrm{Na}(2)-\mathrm{O}(2)$ & $2.36824(14)$ \\
$\mathrm{Na}(1)-\mathrm{O}(1)$ & $1.38816(9)$ & $\mathrm{Na}(2)-\mathrm{O}(2)$ & $3.07809(18)$ \\
$\mathrm{Na}(1)-\mathrm{O}(4)$ & $2.14513(13)$ & $\mathrm{Na}(2)-\mathrm{O}(6)$ & $2.56564(18)$ \\
$\mathrm{Na}(1)-\mathrm{O}(4)$ & $2.14620(13)$ & $\mathrm{Na}(2)-\mathrm{O}(7)$ & $2.12781(12)$ \\
$\mathrm{Na}(1)-\mathrm{O}(5)$ & $2.38305(26)$ & $\mathrm{N}(2)-\mathrm{O}(6)$ & $1.61674(10)$ \\
$\mathrm{Na}(1)-\mathrm{O}(5)$ & $2.95289(33)$ & $\mathrm{Na}(1)-\mathrm{O}(5)$ & $2.38317(26)$ \\
$\mathrm{Na}(1)-\mathrm{O}(5)$ & $2.95298(33)$ & $\mathrm{N}(1)-\mathrm{O}(6)$ & $1.46879(9)$ \\
$\mathrm{Na}(2)-\mathrm{N}(2)$ & $2.87074(19)$ & & \\
$\mathrm{Bond}$ angles & $\left({ }^{\circ}\right)$ & $\mathrm{Bond}$ angles & $\left({ }^{\circ}\right)$ \\
$\mathrm{O} 1-\mathrm{Ga}-\mathrm{O} 2$ & $124.012(5)$ & $\mathrm{O} 2-\mathrm{Ga}-\mathrm{O} 3$ & $138.873(2)$ \\
$\mathrm{O} 2-\mathrm{Ga}-\mathrm{O} 4$ & $112.977(4)$ & $\mathrm{O} 3-\mathrm{Ga}-\mathrm{O} 4$ & $108.039(1)$ \\
$\mathrm{O} 2-\mathrm{Na} 2-\mathrm{O} 7$ & $114.889(3)$ & O3-Na2-O6 & $103.826(7)$ \\
$\mathrm{Ga}-\mathrm{O} 2-\mathrm{Si}$ & $129.571(3)$ & Ga-O4-Si & $121.499(2)$ \\
\hline
\end{tabular}

The data shows that framework atom positions, cation sites and the arrangement of the nitrate group are in good agreement with structural data of other nitrate cancrinite ${ }^{14}$. The bond distance results obtained by Reitveld refinement are; $d(\mathrm{Si}-\mathrm{O})=1.69367 \AA$ and $\mathrm{d}(\mathrm{Ga}-\mathrm{O}))=$ $1.82525 \AA$. The nitrate groups are located inside the main channel with the nitrogen atoms on the $6_{3}$ axis. The refinement shows the nitrate groups with oxygen atoms slightly elongated from the $x-y$ plane perpendicular to the hexagonal axis. Similar to the nitrate aluminosilicate cancrinite ${ }^{15}$ two different types of nitrate groups were found and the oxygen and nitrogen atoms of both groups are refined on different positions. On comparison of present cancrinite with aluminosilicate cancrinite, the substitution of framework $\mathrm{Al}$ by $\mathrm{Ga}$ leads to an expansion of framework. The lattice parameters found in literature ${ }^{16}$ for $\mathrm{NO}_{3}$-AlSi-CAN are, $\mathrm{a}=12.668$ $\AA$ and $\mathrm{c}=5.166 \AA$ and for $\mathrm{NO}_{3}-\mathrm{GaSi}-\mathrm{CAN}, \mathrm{a}=12.77981 \AA$ and $\mathrm{c}=5.20217 \AA$. 


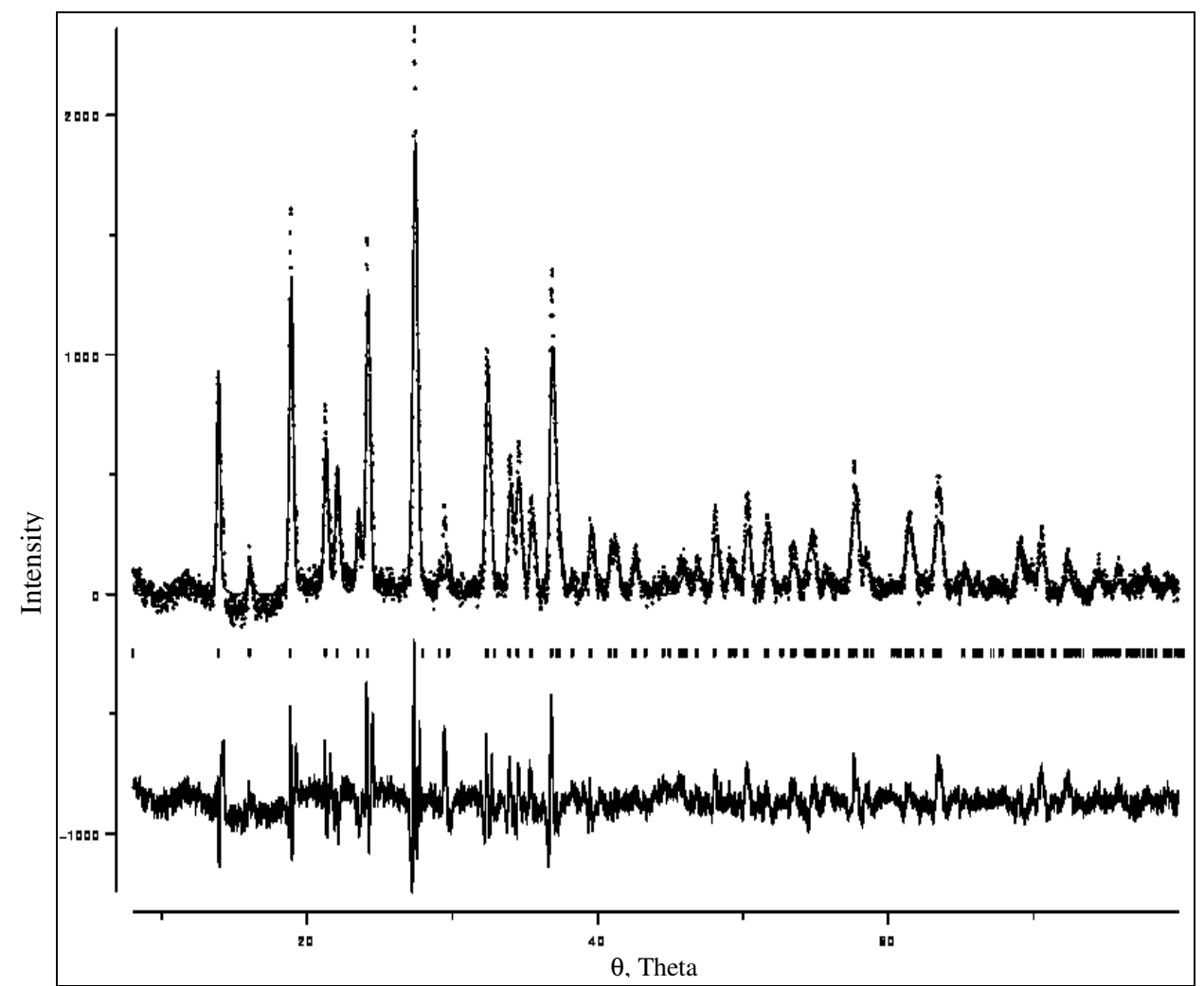

Figure 3. X-ray powder pattern of the nitrate cancrinite. The observed powder pattern together with the difference between observed and calculated intensities (lower part) are given.

MAS NMR spectroscopy

The ${ }^{29} \mathrm{Si}$ MAS NMR and ${ }^{23} \mathrm{Na}$ MAS NMR spectrum of gallosilicate nitrate cancrinite is shown in Figure 4. The ${ }^{29} \mathrm{Si}$ MAS NMR spectrum shows a single absorption peak at $\delta$ iso = $-81.09 \mathrm{ppm}$ for $\mathrm{Si}(\mathrm{OGa})_{4}$ unit indicates a $\mathrm{Si} / \mathrm{Ga}$ ratio of 1.0 and confirms the alternating $\mathrm{Si}$, Ga ordering of the framework ${ }^{17}$. The single line of the MAS NMR spectrum and the chemical shift correlate well with the Si-O-Ga bond angle of the cancrinite.

On comparison with sodalites ${ }^{18}$ which shows quadrupole pattern with two well separated peaks, due to non-spherical symmetric charge distribution around the sodium cations inside the sodalite cages. But, ${ }^{23} \mathrm{Na}$ spectrum of cancrinite shows single line at $\delta$ iso $=$ $10.62 \mathrm{ppm}$, due to spherical symmetry of the field gradient at the sodium sites in the cancrinite. Two different crystallographic positions can not be resolved. This could be an effect of the quadrupolar coupling parameter distribution of both positions and electronic shielding by water for $\varepsilon$-cage position and motional effects for the channel position.

\section{Thermal analysis}

The weight temperature behavior of the gallosilicate nitrate cancrinite is shown in Figure 5. An endothermic behavior in the temperature range of $600-700{ }^{\circ} \mathrm{C}$, is due to the decomposition of encapsulated salt molecules. The thermal analysis shows loss in weight up to $720{ }^{\circ} \mathrm{C}$ and high thermal stability of cancrinite framework thereafter. TGA shows two major weight losses, one up to $600{ }^{\circ} \mathrm{C}$ due to adsorbed and enclatherated water molecules and another 
between $600-720{ }^{\circ} \mathrm{C}$ can be assigned to the decomposition of $\mathrm{NaNO}_{3}$. The weight loss indicates occupancy of cancrinite cages by $\mathrm{NO}_{3}{ }^{-}$anions and water
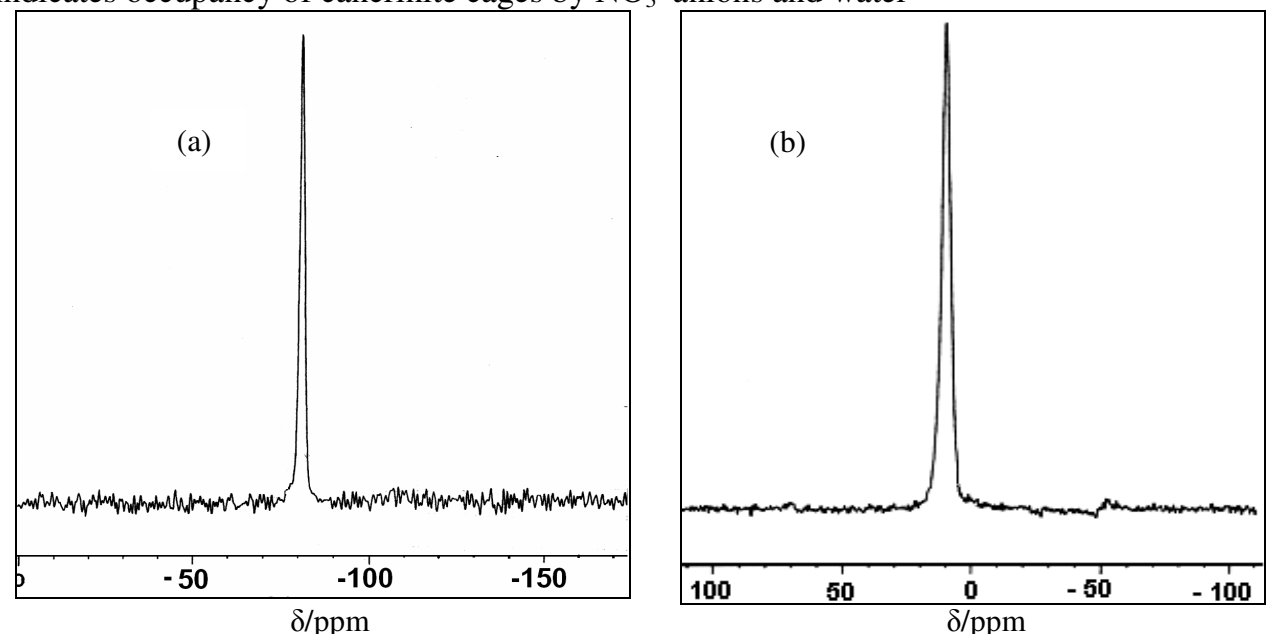

Figure 4. MAS NMR spectra of gallosilicate nitrate cancrinite (a) ${ }^{29} \mathrm{Si}$ MAS NMR (b) ${ }^{23} \mathrm{Na}$ MAS NMR.

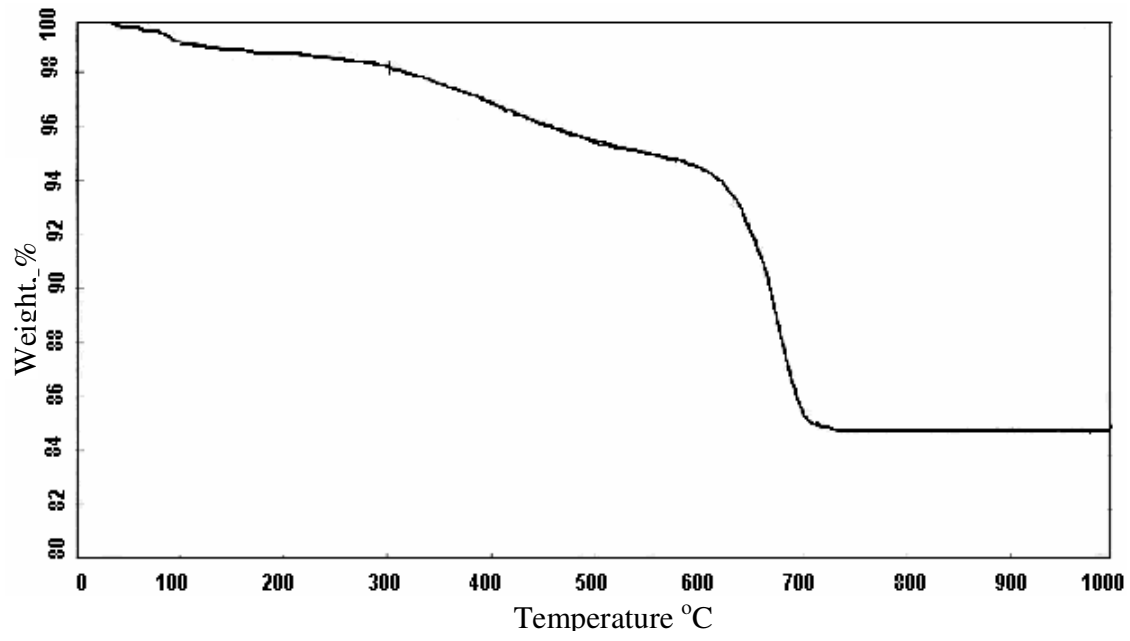

Figure 5. Weight-temperature behavior of gallosilicate nitrate cancrinite.

\section{Crystal morphology}

Scanning electron microscopic study was carried out to provide information about the particle morphology and the macroscopic crystal growth mechanism. It also reveals a relationship between the habit of the cancrinite crystal with type of salt and its concentration in the initial mixture. Figure $6(\mathrm{a} \& \mathrm{~b})$ shows the SEM picture of the synthesized cancrinite loaded with sodium nitrate. SEM shows the crystals with well shaped hexagonal structure. The hexagonal structure supports for the observed unit cell parameters a $=12.77981 \AA$ and $\mathrm{c}=5.20217 \AA$. Atomic proportions in the same product were determined using energy dispersive X-ray Spectroscopy (EDX). EDX analysis has detected that Ga, Si and $\mathrm{Na}$ are present in the crystal with respective compositions. 


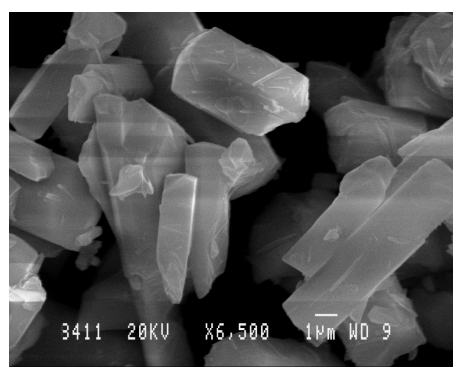

(a)

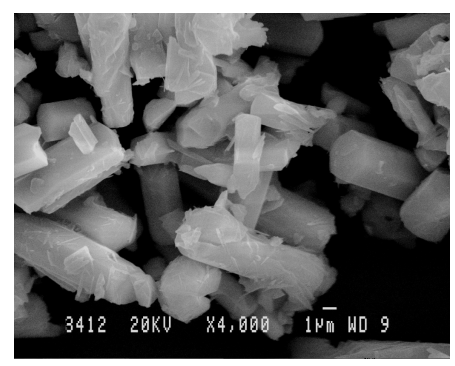

(b)

Figure 6. Scanning electron micrographs of gallosilicate nitrate cancrinite.

\section{Acknowledgments}

Authors are thankful to BCUD Pune for providing funding to this work, Department of physics IIT, Mumbai for providing X-ray powder diffraction and NMR research centre IISc, Banglore for MAS NMR facilities.

\section{References}

1. Pauling L, Proc Natl Acad Sci., 1930, 16, 453-459.

2. Buhl J Ch, Thermochimica Acta, 1991, 178, 19-31.

3. Grundy H D and Hassan I, Can Mineral, 1982, 20, 239-251

4. Norby P, Krogh Andersen I G, Colella C and de'Gennaro M, Zeolites, 1991, 11(3), 248-253.

5. Breck D W, Zeolite Molecular Sieves, structure. Chemistry and use, Wiley, New York, 1974.

6. Hund F, Z Anorg Allg Chem., 1984, 509,153-160.

7. Lindner G G, Hoffrnann K, Wittke K, Reien D, Heinmann Ch and Koch W, J Solid State Chem., 1996, 126, 50-54.

8. Barrer R M and Vaugiian D E W, J Phy Chem Solids, 1971, 3(2-3), 731-743.

9. Lee Y, Parise J B, Tripathi A, Kim S J and Vogt T, Micro Meso Mat., 2000, 39, 445-455.

10. Gesing T M and Buhl J Ch, Z Kristallgra, 2000, 215, 413.

11. Von Dreele R B, J Appl Cryst., 1997, 30, 517-525

12. Kanepit V N and Rider E E, J Struct Chem., 1995, 36, 694-696.

13. Pahor N.B, Calligaris M, Nardin G and Randaccio L, Acta Crystallogr., 1982, B38, 893-895.

14. Buhl J Ch, Thermochimica Acta, 1991, 178, 19-31.

15. Gotticher S and Knochel C D, Acta Crystallogr.,Sec B, 1980, 36, 1271.

16. Buhl J Ch, Stief F, Fechtelkord M, Gesing Th M, Taphorn U and Taake C, J Alloys and Compounds, 2000, 305, 93-102.

17. Engelhardt G, Luger S, Buhl J Ch and Felsche J, Zeolites, 1989, 9, 182-186.

18. Stein A, Ozin G A and Stuky G D, J Am Chem Soc., 1992, 114, 8119-8129 


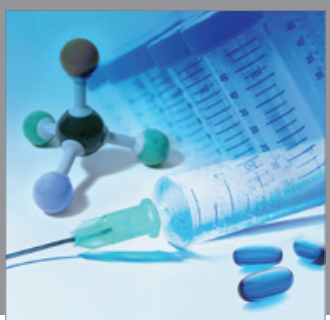

International Journal of

Medicinal Chemistry

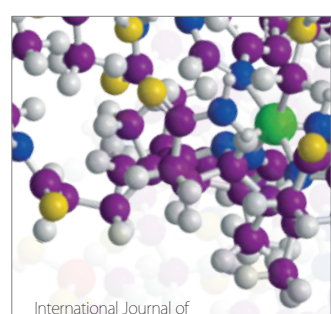

Carbohydrate Chemistry

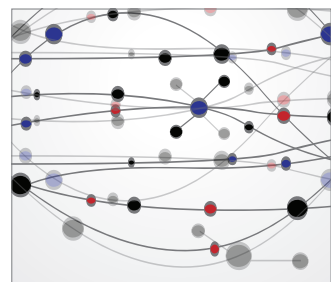

The Scientific World Journal
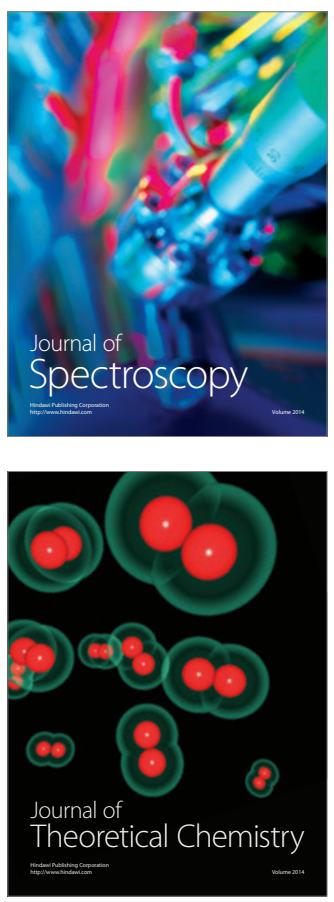
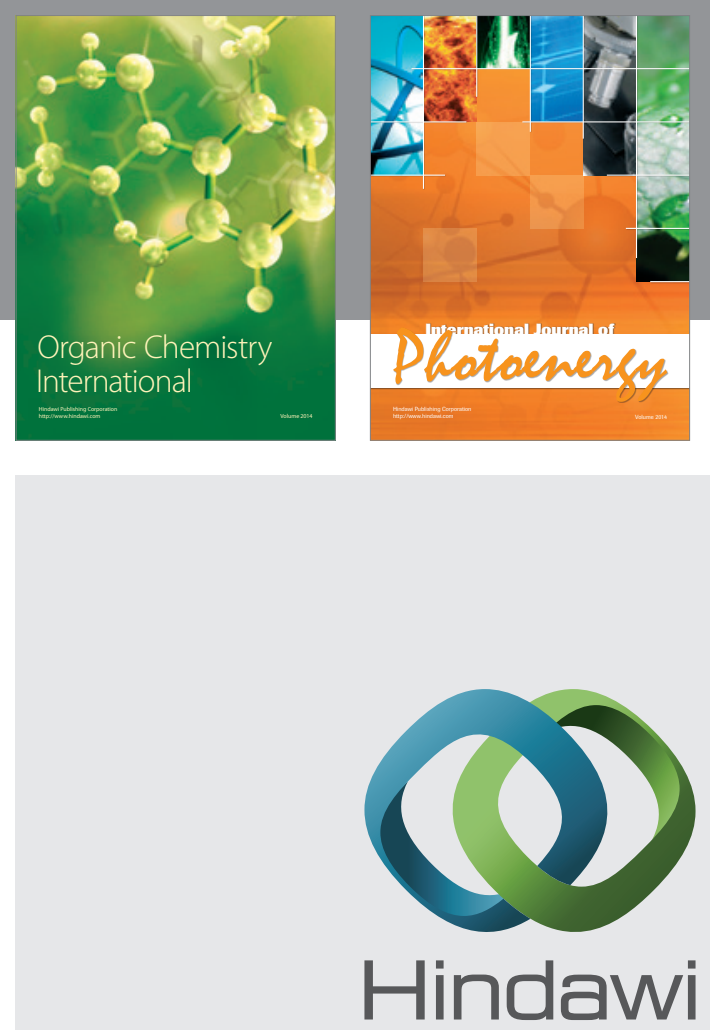

Submit your manuscripts at

http://www.hindawi.com
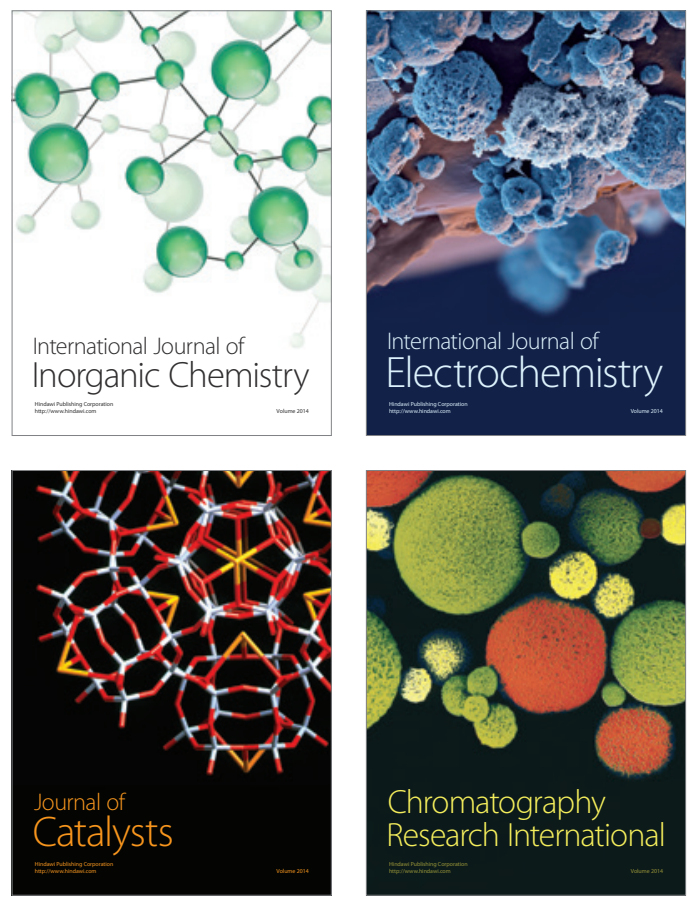
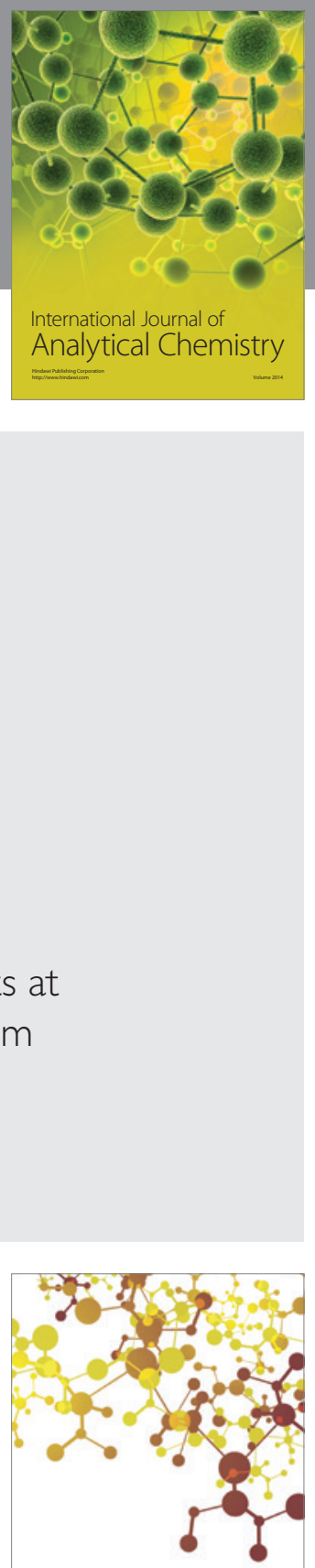

Journal of

Applied Chemistry
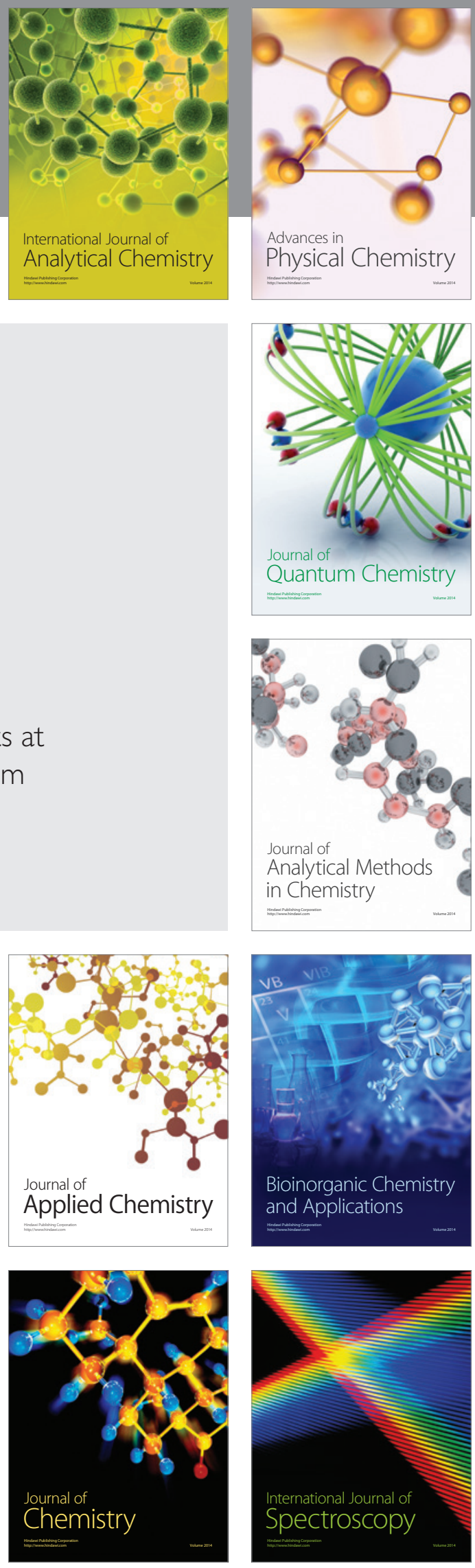